\title{
The Study Of Adjustment Changes After Teaching Of Transactional Analysis(Ta) To The People.
}

\author{
Samira Nejadnaderi ${ }^{*}$, Darehkordia ${ }^{2}$, Divsalar, $\mathrm{K}^{3}$ \\ 1. Psychologist.Neuroscience Research Center- Kerman University Of Medical Sciences, Kerman, Iran. \\ 2.Psychometric. Shahid Chamran University Of Ahvaz, Ahvaz, Iran. \\ 3. Islamic Mysticism,Neuroscience Research Center-Kerman University Of Medical Sciences, Kerman, Iran.
}

\begin{abstract}
Transactional Analysis is the psychology of human relationships.It is system of techniques designed to help people understand and change their feelings and behaviors. In 1958 Eric Berne, an American psychiatrist, formulated this theory. The philosophy of transactional analysis begins with an assumption that we are all ok. The present study investigates adjustment changes after teaching of transactional analysis (TA) to the people.Sample of this research included two groups (control and experimental) of men and women between 20 to 30 years old. The numbers of research samples were 24 people (12 persons in each experimental and control group) that select from clients in one Consulting Center in Kermanrandomly. Test grouptrained transactional analysis theory in 8 week, but control group did not teach. Control and experimental group completed Bell Adjustmentquestionnaires before and after 8 weeks then rate of adjustment measured between two groupsbefore and after teaching of TA theory. Results showed after transactional Analysis (TA) teaching increased people adjustment in different dimension such as: family, emotional, job and social. Transactional analysis teaching canuse to improve adaptation and relationship in couples, parents and child, students, organizations, teachers and other group of people.
\end{abstract}

Keywords: Adjustment, Teaching, Transactional Analysis.

\section{Introduction}

Transactional Analysis theory stated by Eric Berne in 1958. It is good method for personal growth and development, intra psychic functioning and interpersonal behavior. It is system of techniques designed to help people understand and change their feelings and behaviors. It gives picture of how people are structures psychologically. It also provides a theory of communication. This theory helps people to understanding their communication and accepts ofresponsibilitywith regard to what is happening in present [18, 25 and 4]. Philosophy ofTransactional Analysistheoryis thatallpeopleare ok.Allhuman have apotentialinterestanddesire togrowandflourishandthinking capacityto make decisions forthemselves, rather than the decisionsofothers. Transactional Analysis is a method of treatment that can improve vision, intellectual and emotionalTransactional analysis is basically contractual. Anywork done through transactional analysisnecessarily has a contract. Contract is anagreement between the counselor and the client [20].These analyzesarefour categoriesthat include: structuralanalysisoregostates(Parent- Adult-Child) analysisandformsofinteraction,structuringtime (Withdrawal,Rituals, Past time, Activities, Games, ntimacy), and script $[3,18]$. Transactional Analysisisaschool of thoughtand a model fortreatment.Studiesshowthis approachcan lead toimproveself-esteem[24], Qualityof Life[8]andother positive psychologicaloperations[12 and 13]is.Transactional analysis usedindifferentfieldssuch as training for administratorsand teachers, and its effectivenessonstudent performance[25], organization employees toimprove thequality of therelationship andjobsatisfaction[14]andconflictCoupleconflicts[18] thatall of them showed usefulness of treatmentmethod and improve socialcommunicationsand solve conflicts. In the study, Boholest(2003 [5])discussed thestudents' perceptionofselfandothers and their ego stat with teaching transactional analysisincreased. Research by FarhangiandAghaMohammadian(2006 [7])stated trainingTransactional Analysiswould lead to use good method of encounter in differentsituations.On the other hand, adjustment is as skillofsocial andpersonal relationship includesareassuch asjob, social emotionalthat, psychologists are concerned. Anyonewholivesin an environmentmustable to adaptive withit, otherwisenon adjustment can be express as reason of individualfailures. Adjustment requiressupplyingtheindividualneeds ofthe realenvironment[25]. Adjustment is dynamic and each person responses to environment andthe changesthatoccurinit. Determining extentof this successfuldependson two factors: Personalcharacteristics(skills, attitudes, and physical stats)andothersituations thatperson may beencounter(Family Conflicts andworkconflicts). Thesetwo adjustmentfactorscontribute tothesuccess,prosperity andhappinessof people[2].Adjustmenthasdifferentpatterns [15]. People without adjustmentcannot get adaptation and will cut their social relationship by reason of non-adjustmentwith environment.This topic leads to formimpropriate self-conceptand indicatesunstable andabnormalbehaviorindifferentsituations[10]. Study 
ofTalub (1994 [22]) on theeffect of educationTransactional AnalysisTransactional on student adjustment showed thatstudentscanincreasetheiradaptability. With due attention to theeffectivenessoftransactional analysis in encounter ,personal and social conflict resolution,the importance ofadjustmentas partofsocial and personalrelationships, finding appropriateadjustmentstrategiesto improvemental healthproblemwould seemto be necessary. So thisresearch will Study adjustment changes after teaching of transactional analysis (TA) to the people.

\section{II.1. Material}

\section{Materials and Methods}

This research is experimental and designspretest-posttestwith control groupthat study effect oftraining transactionalanalysison the"adjustment "dependent variable. Sample group include24men and women(20-30 years) in theexperimentaland controlgroups(each group $n=12$ ). Participantgrades are undergraduate and postgraduate.

\section{II.2. Tools}

BellAdjustmentquestionnaire:

BellBhyram (American psychologist)was designed BellAdjustmentquestionnairein 1961 that is usedforboth genders.For first time Mrs.Simonnormalized this questionnaire in Iran in 1365. BellquestionnairebyDr.Delawarewas reduced from160questionsto45 questionsin 1372andwas administeredtoveterans[9]. Rezakhani (1999 [17]) normalized this scale and reportedCranach's alpha coefficientof thisscalethat was 0/94 [15].Bell adjustmentquestionnaire include of 160questionsas"yes" and"no " that measurefive-level of family, health, social, emotionalandjob adjustment and finallyachievedatotalscorethatIt will bean publicadjustmentof person.

Transactional AnalysisTopics:

Training chapters selected according tothe proposedtopicsBerneTransactional Analysis(1995). Section titles included:analysis of thestructure oregostates(Parent- Adult-Child), formsofinteractionandrelationships, lifesituations, strokes, scripts, games analysis, and time structuring.

\section{Ii.3. Procedure}

Voluntarily people enrolledincounselingandpsychological servicescenter ofKerman afteradvertising about training transactional analysis. Registeredindividualsrandomlydivided intocontroland experimental groups.Initially the therapist in individual sessions explained about Bell adjustment questionnaire and transactional analysis to each of participants.After participantsagreedto remain these classes. Theycompletedthequestionnaire.The therapistapologized from control group and explained because of arealimitation, the next groupwill traininthe next two months.. The experimental groupmetweekly for8 section 2 hours and according toBern'stheory(1995 [4]) trained topics of transactional analysis. Theexperiment group after completingthe coursecompletedtheBell adjustment questionnaire again. After 2 month the control groupcompletedthequestionnaireagain.

\section{Result}

Covarianceanalysis usedto analyze thedata inthis study. Thestatisticalassumptionssuch ashomogeneityofvariances weredone, and thencovarianceanalysiswas evaluated.

Table 1 showedMeanandstandard deviation of theexperimental and controlgroupsondifferent aspects ofadjustmentinpre-and post-tests.Means of pretest for each groupexplained home, emotional, joband social adjustment weremoderate and health and total adjustment were low level.However,all the adjustment scales have up level in post -test group.

Table 1.Averageand standard deviation of adjustment scales in the test and controlgroups

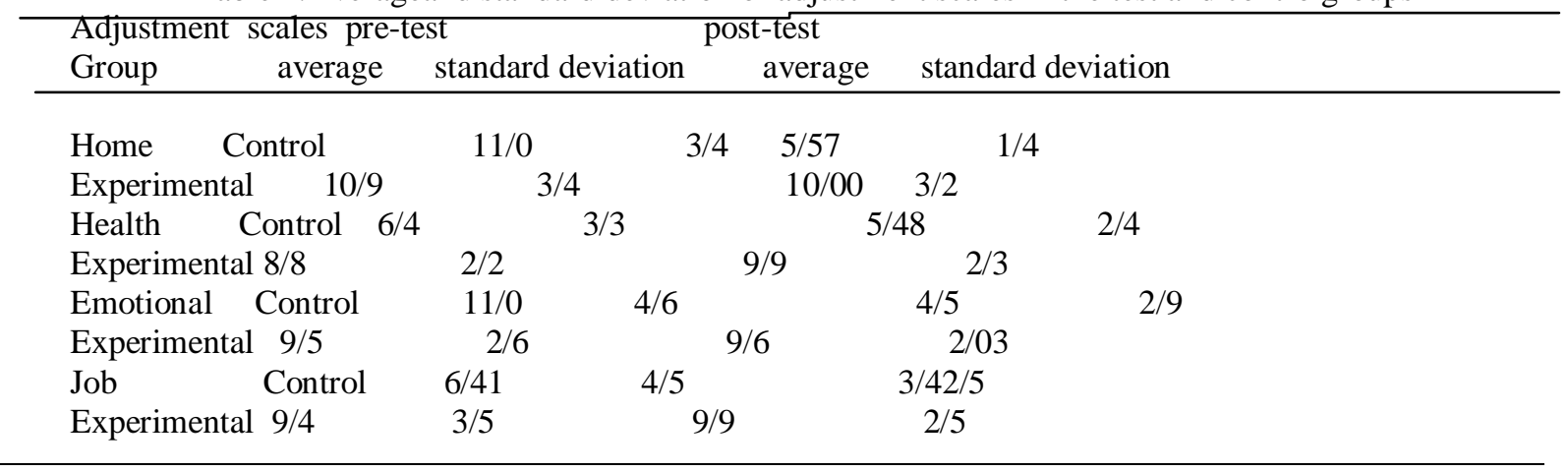


The Study Of Adjustment Changes After Teaching Of Transactional Analysis(TA) To The People.

\begin{tabular}{|c|c|c|c|c|c|}
\hline Social & Control & $11 / 0$ & $4 / 9$ & $4 / 5$ & $2 / 9$ \\
\hline Experimental & $11 / 3$ & $3 / 08$ & $11 / 4$ & $2 / 9$ & \\
\hline Total & Control & $44 / 6$ & $13 / 7$ & $24 / 0$ & \\
\hline Experimental & & & & $0 / 9$ & $1 / 9$ \\
\hline
\end{tabular}

Levine'stestdone forhomogeneityofvariancesandthe results ofthefinalcovariance analysis showed effectoftransactional analysis training on adjustmentgroups.Resultsobtained from thecovarianceanalysis revealedthatthe effect of training were significant onhomeadjustment $(05 / 0=\mathrm{P}, 7 / 5 \mathrm{~F}=, 47 / 0=\mathrm{R} 2)$ and job adjustment $(05 / 0=\mathrm{P}, 4 / 5 \mathrm{~F}=, 47 / 0=\mathrm{R} 2)$. Theeffect oftransactional analysis training were significant on health, $\operatorname{adjustment}(01 / 0=\mathrm{P}, 21 / 8 \mathrm{~F}=, 66 / 0=\mathrm{R} 2)$, theemotionaladjustment $(01 / 0=\mathrm{P}, 8 / 10 \mathrm{~F}=, 53 / 0=\mathrm{R} 2)$, socialadjustment $(01 / 0=\mathrm{P}, 8 / 29 \mathrm{~F}=, 83 / 0=\mathrm{R} 2)$ and total adjustment $(01 / 0=\mathrm{P}, 02 / 12 \mathrm{~F}=, 82 / 0=\mathrm{R} 2)$. So results showed that there were significant different in adjustment scales inpre and post-test group after training of transactional analysis. Transactional analysis training improved adjustment of experimental group.

\section{Disscusion}

This studyexaminedadjustment changes after teaching of transactional analysis (TA) to the people.The resultsof this studyshowed that teaching ofTransactional Analysishad appositive effect on family, emotional,health,job and socialadjustment. The resultsobtained consisted with Talub(1994), Gayol(1997 [8]), Novy (1999 [12]), Novy (2002 [13]), Boholst(2003 [5]), FarhangiandAgha Mohammadiyan(2006 [7]),Salamt(2008 [19])researches. Human is social potentiallythat alwaystriestoacquireskillstofacilitatetheir relationswith others.Adaptationorsocialskills are particular abilities torelationship withothers. (Amidiniya, 2010 [1])The purposeofthis analysisis toliberalizeandstrengthenadultandto eliminatebad feelingsand makea good impression (Salamat, 2008 [19]). Transactional analysisteaching help to remove pathologicalproblems, to access unifiedmethods adult and independent and freedom from inefficient life script.Transactional analysis training lead person to remain in here and now status andcanpromoteselfrealizationandemotionalandfunctionalindependence (Torkan,2007 [23]).Transactional analysis is the systematic tool for anybody for their development. The client can use his adult to confirm the reasonableness of any new behavior.So, thepersonsseek recognition oftheiregostates, drivers and disincentivesand strengthentheirconfronting strategies in life conflicts. These conflicts include of: familyconflict, marital relationship job positions, behavior style withotherpeople in societyand emotionalsituations. Personstrytodeciderationally andadeptly in these situations.Actually, these changes in personslead to improveself-esteem, quality of life, job, and social performanceand in other word,improve different dimension of adjustment.

\section{Conclusion}

According to, transactional analysis training has positive impact onsocialand personal relationship, teaching of transactional analysis theory in universities and Schools can learn topeople the adaptationskills. So psychologists and officials can plan to learn this theory for improve of student adjustment. Because the theory ofTransactional Analysishas aspecial emphasisonthegolden age of thechild, then thefamily is very important ascentralenvironmentsinpsychological, social and physicalhealthof child. So quality ofinteraction betweenparent-childand training adjustment skills are necessary by parent that psychologists can use this theoryto increase parent information.

\section{Acknowledgements}

Here, thanks from the Neuroscience Research Center- Kerman University of Medical Sciences, counseling center andrespectedclientswhohavehelpedusinthisstudy.

\section{References}

[1] A. Amidiniya, A. Nisi, M.Soodani, The Self seem and Rate of individual- social adjustment in girl student, Thought and Behavior in Clinical Psychology, 5(7), 2010,35-40.

[2] H.Azad, Abnormal psychology.Tehran.Besat publication, 1996,212.

[3] A.Bern,Games people play: the psychology of human relationship. Translated by Fasih, E. Tehran, Iran,Asim publication, 1981, $34 \mathrm{p}$.

[4] A.Bern,Transactional analysis. Translated by Fasih, E. Tehran, Iran, Fakhteh publication, 1995, 45.

[5] A. Boholst, Effects of Transactional Analysis Group Therapy on Ego States and Ego State Perception,Published in the Transactional Analysis Journal, 33, (3), and 2003, 254-261.

[6] p. Copland,C .A. Borman, Affective Education: Effects of Transactional Analysis Training on Seventh Grade Students (A Summary of Two Dissertations). ERIC Journal, 4(12), 2005, 201-212.

[7] R. Farhangi,Mohamadiyan.H, The study of impact of Group Psychotherapy on stress coping styles in adolescences based on transactional analysis approach. Studies in Edeucation \&Pasychology.7(2), 2006, 41-62.

[8] G, n. Gayol,Dyagnosis and treatment of ego state of boundary problem, Effect on self-steem and quality of life,Transactional analysis Journal, 27, 1997, 236-241. 
The Study Of Adjustment Changes After Teaching Of Transactional Analysis(TA) To The People.

[9] MH.Ghasemi the effects of social adjustment in cannabis addiction among students of Tehran. National Conference on Addiction Tehran, 2002, 45p.

[10] E. Kazemi, A. Noori, A.GHolizadeh, Study on relationship between self-concept and social adjustment between staff in Office of culture and Islamic Guidance,Knowledge \& Research in Applied Psychology, 17(3), 2003,101-118.

[11] L.Lawrenc, Applying Transactional Analysis and Personality Assessment to Improve Patient Counseling and Communication Skills. AmJ Pharm Educ, 15 (4), 2007, 71-81.

[12] T,V.Novy,The effectiveness of transactional analysis, Transactional Analysis Journal, 29, 1997, 18-30.

[13] T, B.Novy, Measuring the effectiveness of transactional analysis: An international study. Transactional Analysis Journal, 32, 2002, $8-24$.

[14] N. Nykodym, O,C. Longeneker, W. Ruud,N.Improving Quality of Work Life with Transactional Analysis as an Intervention Change Strategy,Applied Psychology, 40(4), 2007,395-404.

[15] H.Pasha sharifi,The Introductory study of Gardner's multiple intelligence theory, in the field of lesson subjects and the students' compatibility, Quarterly Journal of Educational Innovations, 24, 2008, 12-20.

[16] A.Poor Moghadas, Adjustmentpsychology. Esfahan, Mashal publication, 1989, 230p.

[17] S. Reza khani, Standardization Bell adjustment questionnaire. [MSc thesis]. Azad Islamic Of Roodhen University, 1999, 76p.

[18] A. Shafi Abadi, Theories of Counseling and Psychotherapy, Tehran, University publication. 1997, 56p.

[19] M. Salamat, A. Zamani, A. Alahyari, The effect of teaching communication skills on marital conflict by transactional analysis. Journal of AppliedPsychology, 1(3), 2008, 28-42.

[20] N. Sani,S.Karimi,Transactional analysis counseling: introduction. BRAC Unuversity Journal. 2(1), 2005, 117-120.

[21] I. SteWart, V.Jonez,today: anew introduction to transactional analysis. Translated by Dadgostar, B. Tehran, and Iran. Dayereh publication, 2004, 342p.

[22] E.Talub, Using transactional analysis to enhance adjustment in Filipino college students,Transactional Analysis Journal, 24, 1994, 197-205.

[23] H. Torkan, M. Kalantari, H.Molavi, The efficacy of transactional analysis group therapy in marital satisfaction.Family Research J, 2(8), 2007, 389-393.

[24] L. M. Wissink, validation of transactional analysis in increasing self-esteem among participants in a self-representing program, Transactional Analysis Journal,24, 1994, 189-196.

[25] A. Yoosefi,F.Karimi, Study on relationship pattern of schools mangers in Esfahan based on transactional analysis approach. Knowledge \& Research in Psychology, 2(6), 2002, 136-140. 